\title{
EX-ESCRAVAS E LIBERTAS NO PÓS-ABOLIÇÃO: PEQUENAS E SILENCIOSAS CONQUISTAS (SÃO JOSÉ DOS CAMPOS/ SP/ 1888)
}

\author{
Raquel de Souza Martins Lima ${ }^{1}$ \\ Maria Aparecida Ribeiro Papali ${ }^{2}$
}

Resumo: Este trabalho tem o objetivo de discutir novas posturas de mulheres libertas no período do pósabolição, a partir da interpretação de experiências vividas por elas. Com o fim da escravidão, novas condições sociais são instauradas na sociedade brasileira e a partir delas será construída a identidade das mulheres pobres e libertas no Brasil e possui clara ligação com as relações de trabalho, preconceitos raciais, exclusão social, relações hierárquicas familiares, vividas ainda hoje no Brasil. A investigação se deu por meio da interpretação de um processo de tutela de órfãos do ano de 1888 , do $2^{\circ}$ Cartório de São José dos Campos - SP.

Palavras-chave: Pós-abolição; Liberta; Mulher; Identidade; Direitos.

\footnotetext{
${ }^{1}$ Curso de História/Univap - Universidade do Vale do Paraíba, Brasil. E-mail: rsmartins@uol.com.br.

2 Curso de História/Univap - Universidade do Vale do Paraíba, Brasil. E-mail: papali@univap.br.
} 